\title{
Principal Preparation Programs: Perceptions Of High School Principals
}

Ronald A. Styron, Jr., Ed.D., University of Southern Mississippi, USA

Steven D. LeMire, Ph.D., University of North Dakota, USA

\begin{abstract}
There has been an abundance of research documenting perceived deficiencies in traditional principal preparation programs, but little field data have been collected. As such, the authors of this study sought to assess the satisfaction of practitioners, high school principals, with their preparation programs. Questionnaires were received from 374 participants located at schools within four southeastern states. Using descriptive and inferential statistics, data were generated and analyzed illustrating frequency of response, means, and standard deviation from 13 key questions relating to the principalship. Findings included apparent content with preparation programs in all areas of responsibility identified with the exception of preparation for addressing the needs of special populations. These findings could be of importance to universities as they reorganize principal preparation curriculum to be more connected to $K-12$ issues.
\end{abstract}

Keywords: Principal Preparation Programs, Principal Certification, Principal Preparation Curriculum

\section{INTRODUCTION}

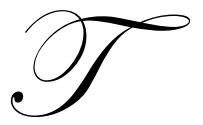

he existence of a principal shortage has been the subject of intense debate over the last several years (Pounder, Galvin, \& Shepard, 2003). United States Secretary of Education Roderick Paige (United States Department of Education, 2003) contended that the principal shortage resulted from a dramatic increase in principal retirement. As found in The Bureau of Labor Statistics Occupational Outlook Handbook (United States Department of Labor, 2007), over the next 10 years there may be as much as a $40 \%$ turnover in school leaders representing 40,000 principal and assistant principal positions.

Gates, Ringel, and Santibanez (2003) discovered that there were substantial variations in career incentives for potential educational leaders at the state and local levels, and that there were barriers to entry that discouraged teachers from becoming administrators. Given the need to attract high-quality instructional leaders to schools and the declining numbers of uniquely qualified applicants seeking these posts means district leaders are often faced with the challenge of designing programs to train and develop principals to better meet the complex demands of instructional leadership.

Today, school and district leadership characteristics are defined by scientific-based research, rigor, accountability, responsibility for teacher quality, utilization of data and research, and the ability to compete in a public choice environment. Within the environment created by No Child Left Behind, principals must rely on a keen sense of how to use accountability to lead data-driven decision-making; a desire to challenge conventions; the ability to lead a team; and motivate, mentor, and manage personnel. Unfortunately, traditional preparation programs leading to certification do little to prepare prospective administrators (teachers) for these responsibilities (Hess, 2006). Many university-based principal preparation programs do not prepare teachers for the challenges of 21 st century educational leadership.

School principals are widely regarded as gatekeepers of student success (Stiggins, 2002). Principals shape and implement policies that influence school practices and performance. Therefore, because of the crucial role that a principal has pertaining to student achievement, principal preparation has received a great deal of attention recently. Since much of this attention has resulted in literature critical of principal preparation programs, the researchers 
involved with this project set out to gather information about how current principals felt about their preparation. As a result, within this work, data were collected regarding the level of satisfaction that current principals had with their preparation programs related to their roles with student achievement, school management, special populations, and communication. The data were also disaggregated by the difference in levels of satisfaction between traditionally certified and alternatively certified principals, and for principals in their current position less than 5 years and greater than 5 years to help determine if there were any correlations between these factors and levels of satisfaction with preparation programs.

The purpose of this study was to assess if practicing principals felt their preparation program, culminating in traditional or alternative state certification, had equipped them with the necessary skills to handle key administrative roles. After a review of related literature by a panel of experts consisting of professors with recent K12 administrative experience, these key roles were identified as those related to the improvement of student achievement, school management, special populations, and communication.

\section{RELEVANT LITERATURE}

\section{The Principalship}

"Schools won't improve until average building leaders begin to work cooperatively with teachers to truly, meaningfully oversee and improve instructional quality" (Schmoker, 2003, p. 29). Education and business leaders are well aware that administrators play a pivotal role in school improvement and must be supported through comprehensive training and development opportunities. However, the current challenges faced by administrators on a day-to-day basis are not easily addressed in preparation and professional development courses alone.

While working to achieve instructional changes, principals must also address the suitability of today's schooling processes for the current generation of children. To be successful, leaders of our schools require more than traditional course preparation and occasional on-the job training. They must also understand the social and economic pressures of their communities and the necessity of working with and through others to achieve measurable results (Schmoker, 2003).

Beck and Murphy (1994) discussed four forces that are shaping our conception of the role of school administrators: accountability, economic conditions, social forces, and the post-industrial world. Standardized testing is the measure by which administrators are now held most accountable. A basic assumption of accountability programs, which place great emphasis on standardized testing, is that strong principals foster better teaching that in turn fosters greater learning and higher levels of student achievement. Economic forces also drive public conceptions of school administrators. Principals are called upon to reverse the downward spiral of schools as it relates to economic conditions.

Principals are expected to adapt to changing conceptions of leadership. As bureaucracies are replaced with work teams, leaders must acquire a new set of skills and influences that rely less on hierarchy and formal power and more on visionary leadership, interpersonal influence, effective communication practices, varying leadership styles, knowing legal and ethical issues, providing safe and results-driven school cultures, and promoting teacher growth that impacts student achievement. With these forces shaping the role, administrators must now be educators, servants, moral agents, social activists, partners in a community, and architects in new organizational contexts (Beck \& Murphy, 1994).

\section{Principal Preparation}

Because of the prominent role ascribed to administrators in reform reports, educational administration programs are challenged to ensure that principals would be able to restructure school settings, learn new roles, and serve as a catalysts for change (American Association of Colleges for Teacher Education, 1988; Fuhrman \& Elmore 1990; Firestone, Schorr \& Monfils, 2004). Not only must school leaders perform what Elmore (2000) calls "the ritualistic tasks of organizing, budgeting, managing, and dealing with disruptions inside and outside the system" (p. 5-6), today's instructional leaders must be able to coach, teach, and develop the teachers in their schools. They must 
be steeped in curriculum, instruction, and assessment in order to supervise a continuous improvement process that measures progress in raising student performance. They must build learning communities within their schools and engage the broader school community in creating and achieving a compelling vision for their schools. Principals are now seen as a key change agent in school reform.

Traditional preparation programs. Data from the U.S. Department of Education's National Center for Education Statistics (2003-2004) indicated that of the average public school principals who were newly hired, $83.5 \%$ participated in traditional preparation programs leading to full standard state administrative certification.

Approximately 450-500 university programs currently offer principal leadership preparation programs including Master's (472 learning institutions), Specialist's (162 institutions) and Doctoral (472 institutions) degrees. University graduate schools are the primary means for preparing principals and administrators for school and district leadership positions around the nation (Young \& Brewer, 2008).

As indicated by data provided by the United States Department of Education (2003), traditional preparation programs lack vision, purpose, and cohesion. The United States Department of Education also reported university students were often required to take classes that were out of synch with actual practice and the needs of a particular school. Hess and Kelley (2005) asserted graduate schools of education lacked the capacity necessary to make anything more than superficial changes to their existing programs and were in no hurry to change their programs. Graduate schools usually do nothing more than hope aspiring principals are prepared for their role in improving curriculum, instruction, and student achievement.

Levine (2005) contended the majority of principal preparation programs range from inadequate to appalling. University programs are "engaged in a counterproductive race to the bottom in which they compete for students by lowering admission standards, watering down coursework and offering faster and less demanding degrees" (p. 1). While not necessarily an advocate of alternative preparation programs, he painted a bleak picture of traditional preparation programs found at universities as they were pressured to increase enrollment and become dependent on leadership preparation programs as a major source of revenue. Consequently, universities have diminished the quality of their programs to increase student enrollment.

Farkas, Johnson and Duffet (2003) released a study revealing that 67 percent of principals reported principal leadership programs in graduate schools of education were out of touch with the reality of what it would take to successfully lead a school. Hess and Kelley (2007) examined course units and required readings contained in 210 syllabi collected from a sample of 31 principal preparation programs. Results from their study showed that aspiring principals in today's preparation programs were poorly prepared for the problems facing 21 st century schools. In the age of No Child Left Behind, there must be programmatic changes to include courses aimed at improving student achievement. Additionally, tradition programs must include a sound internship with site-based mentoring (Southern Regional Education Board, 2007).

As a rule, university courses found within principal preparation programs have little connection to each other or relevance to the demands and expectations of modern-day administrators. Admission standards are set low and scholarship is poor, thus encouraging those interested in receiving an advanced degree the opportunity to do so with minimal credentials and effort. There is an over-reliance on adjunct faculty, many full-time professors have little or no administrative experience, and those who do tend to have dated experience (Levin, 2005).

Alternative preparation programs. While alternative principal preparation programs vary widely from state to state, six innovative alternative principal preparation programs across the country have been identified by the United States Department of Education and published in the Innovation in Education Series as models (United States Department of Education, 2004). They include the New Jersey Study, the Boston Principal Fellowship Program, the First Ring Leadership Academy, the Leadership Academy and Urban Network for Chicago, the New Leaders for New Schools, and the Principals Excellence Program. As such, they are included in this work to help delineate the framework of alternative programs. 
Due to the crisis in the number and quality of principal applicants in New Jersey, an accelerated program was created with the support of the State Department of Education. This alternative education program had to be approved by the state legislature and also required a change in the New Jersey Administrative Code. It was approved in 2002 and began in January 2003. The program was aligned with the New Jersey Professional Standards for School Leaders and the National Technology Standards for School Administrators (TSSA).

The Boston Principal Fellowship Program was launched through the district's School Leadership Institute. It was designed to prepare principals who could hit the ground running in some of the most challenging schools in the district. This partnership included the University of Massachusetts, the Board Foundation, and the U.S. Department of Education. Once the fellows complete the program, they meet with district administrators to pursue available administrative positions for the upcoming school year.

First Ring describes the suburban school districts that surround Cleveland. These districts experienced some of the same difficult issues as those facing the urban school districts. This led to the establishment of The First Ring Leadership Academy that was composed of First Ring Superintendents concerned with the shortage of school principals in their districts. They collaborated with Cleveland State University, the Ohio Department of Education, the U.S. Department of Education, and local foundations. The superintendents nominated candidates for the program, and it was evaluated by an independent research organization.

The Leadership Academy and Urban Network for Chicago (LAUNCH) began in 1998 and included candidates from the ranks of assistant principals and teacher leaders. It was one of five professional development programs created under the guidance of the Chicago Principals and Administrators Association. Following a panel interview with experienced principals, central office administrators, and a representative from the Broad Foundation, the candidates participated in a rigorous elementary and secondary educational program. These participants (called fellows) made a commitment to stay in the Chicago system for 4 years upon conclusion of their training. More than 188 individuals completed the training program, and it was so well received that the Broad Foundation used it to showcase its benchmarking report.

Three co-founders, a former education policy advisor for the Clinton administration, an education reform advocate specializing in charter schools, and a management consultant, began New Leaders for New Schools in New York, Chicago, Washington, D.C., Memphis, and San Francisco. It became the first nonprofit entity to win an award in Harvard Business School's annual business plan contest. New Leaders' candidates are nationally recruited with many individuals outside the typical applicant pool. Candidates went through a 4-day application process and were required to make a long-term commitment to the district in which they were placed.

The Principals Excellence Program (PEP) is comprised of a partnership between the University of Kentucky and eastern Kentucky's Pike County School District with cooperative efforts from Morehead State University. The main focus of this project was to enhance the skills of school administrators in high-need Appalachian schools. Candidate nominations were solicited from practicing principals, teachers and other educational personnel who perceived their leadership potential. This program received grant funding through the Leadership Development Program from the U.S. Department of Education.

In 2004, the Southern Regional Education Board (SREB) published a report on the progress of developing school leaders in their Challenge to Lead series. Sixteen states were tracked including Alabama, Arkansas, Delaware, Florida, Georgia, Kentucky, Louisiana, Maryland, Mississippi, North Carolina, Oklahoma, South Carolina, Tennessee, Texas, Virginia, and West Virginia. Six indicators were used to determine success in attaining a quality leader in every school. Twelve of the 16 states made progress towards developing a two-step system to license principals. However, only four states made progress towards creating alternative pathways for initial principal certification (Delaware, Louisiana, Oklahoma, and Virginia). This two-step system, which has been adopted by SREB, required principals to complete two or more requirements in order to move from initial certification to advanced licensure.

In 2006, Oklahoma implemented an alternative pathway to principal licensure for individuals with a master's degree in any field, 2 years of relevant supervisory/administrative work experience, and passing scores on 
designated tests. The process required candidates to work with a university to develop individually prescribed coursework. The candidate received a 3-year license while working in an administrative position and completing coursework. Following successful completion of the administrative position and coursework, the candidate was issued a regular administrative license.

\section{RESEARCH QUESTIONS}

The study was guided by the following research questions:

1. What was the level of satisfaction pertaining to principal preparation programs?

2. Was there a difference in the level of satisfaction among principals who completed alternative and traditional principal preparation programs?

3. Were years in the current position a factor in the satisfaction of principals with their preparation programs?

For the purpose of this study, traditional principal preparation was defined as the customary method of principal licensure including the successful completion of sequenced courses found within a university degree program. Alternative principal preparation was defined by each state. Participants were asked to self-selected their method of preparation.

\section{METHOD}

\section{Participants}

Questionnaires were mailed during the fall of 2007 to high schools located in the southeastern region of the United States and included the states of Mississippi, Alabama, Arkansas, and Louisiana. These states were selected because they offered alternative preparation programs and certification for school principals. Participants were composed of building-level administrators including high school principals and assistant principals. Although for the most part grade configurations in these schools included grades 9-12, there may have been some grade configurations other than 9-12. But for the purpose of this study, the high school classification determined by each state department of education was honored. Therefore, researchers considered a school as 'high school' if labeled that way.

\section{Instrument}

The survey instrument contained questions developed to assess four principal preparation categories-student achievement, school management, special populations, and communication. The category of student achievement assessed preparation to assess school and individual student data and manage accountability plans. The second category of school management assessed preparation to manage a school's budget, personnel, and students. The third category of special populations assessed preparation to oversee special education topics such as individual education plans, discipline, and testing. The fourth category of communication assessed preparation to manage communication with the community, school board, and stakeholders. For each of the questions, a scale of 1 to 6 was used with strongly disagree being ranked as 1 and strongly agree ranked as 6.

\section{Design}

The comparisons of type of preparation program and years in current service were compared with independent $t$ tests. The independent variables were type of preparation program and years in current position. The dependent variables were the average of the questions in each subscale of student achievement, school management, special populations, and communications. The subscales were treated as conceptually independent and analyzed separately, and given their own type I error rate. 


\section{Procedure}

Individual surveys were sent by mail in the fall of 2007 to the principals along with a postage-paid return envelope. The instructions on the survey said, "Please take a minute to complete the survey below. The purpose of this survey is to assess and help improve current certification programs for high school administrators. We appreciate your time and willingness to help make the certification process better." The participants were informed that their response on the survey would be confidential. Two weeks after sending out the surveys, a reminder letter was sent to all of the participants asking them if they had not already done so to please complete and return the survey.

\section{FINDINGS}

There were 374 total responses to the 1,100 mailed surveys resulting in a $34 \%$ response rate. Eleven of the returned surveys were only partially completed. Table 1 shows the demographic information of the respondents.

Table 1

Demographic Information of the Respondents

\begin{tabular}{|c|c|c|}
\hline & $f$ & $\%$ \\
\hline \multicolumn{3}{|l|}{ Gender } \\
\hline Male & 265 & 71 \\
\hline Female & 109 & 29 \\
\hline \multicolumn{3}{|l|}{ Position } \\
\hline Principal & 347 & 96 \\
\hline Assistant Principal & 16 & 4 \\
\hline \multicolumn{3}{|l|}{ Certification Program } \\
\hline Traditional & 363 & 96 \\
\hline Alternative & 11 & 4 \\
\hline \multicolumn{3}{|l|}{ Highest Degree } \\
\hline Bachelor & 0 & 0 \\
\hline Master's & 187 & 51 \\
\hline Specialist & 125 & 34 \\
\hline Doctorate & 51 & 15 \\
\hline \multicolumn{3}{|c|}{ Years in current position } \\
\hline Less than 5 years & 232 & 64 \\
\hline Five or more years & 133 & 36 \\
\hline \multicolumn{3}{|l|}{ Race } \\
\hline Black & 50 & 16 \\
\hline White & 313 & 84 \\
\hline
\end{tabular}

Overall Sample, $n=374$

The individual questions within each of the subscale categories related to student achievement, school management, special populations, and communication were averaged to obtain individual scores for each respondent. Measures of reliability for the subscales are shown in Table 2.

Table 2

Measures of Internal Consistency of the Subscales

\begin{tabular}{llc}
\hline \multicolumn{1}{c}{ Sub Scale } & Questions & Cronbach Alpha \\
\hline Student Achievement & $\mathrm{q} 1, \mathrm{q} 2, \mathrm{q} 3$ & 0.95 \\
Student Management & $\mathrm{q} 4, \mathrm{q} 5, \mathrm{q} 6, \mathrm{q} 7$ & 0.88 \\
Special Populations & $\mathrm{q} 8, \mathrm{q} 9, \mathrm{q} 10$ & 0.94 \\
Communication & $\mathrm{q} 11, \mathrm{q} 12, \mathrm{q} 13$ & 0.90 \\
\hline
\end{tabular}


Overall, a large percentage of the respondents indicated some form of agreement that their preparation program had prepared them for their current position for student achievement, school management, and communication. The exception to this was special populations. For special populations, nearly half of the respondents indicated some form of disagreement that their preparation program had prepared them for these tasks (Table 3).

Table 3

Percentage of Agreement and Disagreement for Each Question

\begin{tabular}{|c|c|c|c|c|}
\hline Question & Construct & $\begin{array}{l}\text { My certification program has prepared me } \\
\text { to _ } \quad \text { in my current position. }\end{array}$ & $\begin{array}{l}\text { Percentage of some } \\
\text { form of Disagree }\end{array}$ & $\begin{array}{l}\text { Percentage of some } \\
\text { form of Agreement }\end{array}$ \\
\hline 1. & $\begin{array}{l}\text { Student } \\
\text { Achievement }\end{array}$ & understand and interpret school data & $26 \%$ & $74 \%$ \\
\hline 2. & $\begin{array}{l}\text { Student } \\
\text { Achievement }\end{array}$ & $\begin{array}{l}\text { assess test data for individual student } \\
\text { achievement }\end{array}$ & $31 \%$ & $69 \%$ \\
\hline 3. & $\begin{array}{l}\text { Student } \\
\text { Achievement }\end{array}$ & manage my school's accountability plans & $31 \%$ & $69 \%$ \\
\hline 4. & $\begin{array}{l}\text { School } \\
\text { Management }\end{array}$ & handle the school budget & $24 \%$ & $76 \%$ \\
\hline 5. & $\begin{array}{l}\text { School } \\
\text { Management }\end{array}$ & hire school personnel & $19 \%$ & $81 \%$ \\
\hline 6. & $\begin{array}{l}\text { School } \\
\text { Management }\end{array}$ & $\begin{array}{l}\text { manage nonrenewal/termination of school } \\
\text { personnel }\end{array}$ & $31 \%$ & $69 \%$ \\
\hline 7. & $\begin{array}{l}\text { School } \\
\text { Management }\end{array}$ & handle general student discipline problems & $20 \%$ & $80 \%$ \\
\hline 8. & $\begin{array}{l}\text { Special } \\
\text { Populations }\end{array}$ & $\begin{array}{l}\text { handle Special Education student discipline } \\
\text { problems }\end{array}$ & $37 \%$ & $63 \%$ \\
\hline 9. & $\begin{array}{l}\text { Special } \\
\text { Populations } \\
\end{array}$ & manage IEPs & $45 \%$ & $55 \%$ \\
\hline 10. & $\begin{array}{l}\text { Special } \\
\text { Populations } \\
\end{array}$ & $\begin{array}{l}\text { manage scheduling for IEPs and Special } \\
\text { Education testing }\end{array}$ & $50 \%$ & $50 \%$ \\
\hline 11. & Communication & handle community relations for my school & $14 \%$ & $86 \%$ \\
\hline 12. & Communication & manage school board relations & $24 \%$ & $76 \%$ \\
\hline 13. & Communication & communicate with school stake holders & $15 \%$ & $85 \%$ \\
\hline
\end{tabular}

The average percentage for some form of agreement that their preparation program had prepared them for the questions relating to student achievement, school management, and communication was $77 \%$. The average for special populations was $56 \%$. There was no evidence of any association between principals in traditional preparation programs versus alternative preparation programs and principal's years in current position and the categories related to student achievement, school management, special populations, and communication.

Of the 374 respondents, 11 identified themselves as alternatively certified. The traditional and alternative groups were analyzed using independent sample $t$ tests for each of the scales. Each test was given a type I error rate of 0.05 . There was no evidence of differential satisfactions for traditional or alterative preparation for any of the subscales, as shown in Table 4.

Table 4

Results of Independent Sample t tests Comparing Traditional Versus Alternative Certification and Satisfaction of Program Preparation

\begin{tabular}{|c|c|c|c|c|c|c|}
\hline & $\begin{array}{c}\text { Traditional } \\
n=351\end{array}$ & $\begin{array}{c}\text { Alternative } \\
n=11\end{array}$ & & & & \\
\hline Category & $M$ & $S D$ & $M$ & $S D$ & $t(360)$ & $\operatorname{Pr}>|t|$ \\
\hline Student Achievement & 4.1 & 1.3 & 4.6 & 1.5 & -1.12 & .262 \\
\hline School Management & 4.3 & 1.1 & 4.3 & 1.3 & 0.17 & .863 \\
\hline Special Populations & 3.7 & 1.3 & 4.2 & 1.1 & -1.29 & .198 \\
\hline Communication & 4.4 & 1.1 & 4.8 & 1.2 & -1.04 & .299 \\
\hline
\end{tabular}


Of the 374 respondents, 133 identified themselves as being in their current position 5 or more years. The principals in their current position less than 5 years were compared with those in their current position 5 or more years using an independent sample $t$ tests for each of the sub scales. Each test was given a type I error rate of 0.05. There was no evidence of differential satisfactions for any of the subscales, as shown in Table 5.

Table 5

Results of Independent Sample t tests Comparing Principals in Their Current Position Less Than 5 Years Versus More Than 5 Years and Satisfaction with Program Preparation

\begin{tabular}{|c|c|c|c|c|c|c|}
\hline & $\begin{array}{c}\text { Less than } 5 \text { years } \\
n=230\end{array}$ & $\begin{array}{r}5 \text { or } n \\
n\end{array}$ & & & & \\
\hline Category & $M$ & $S D$ & $M$ & $S D$ & $t(360)$ & $\operatorname{Pr}>\mid t$ \\
\hline Student Achievement & 4.1 & 1.3 & 4.0 & 1.3 & 0.39 & .698 \\
\hline School Management & 4.3 & 1.2 & 4.3 & 1.0 & -0.05 & .962 \\
\hline Special Populations & 3.7 & 1.3 & 3.5 & 1.2 & 1.46 & .644 \\
\hline Communication & 4.4 & 1.2 & 4.6 & 1.0 & 1.49 & .136 \\
\hline
\end{tabular}
$p<.05$

To further assess if there was an association between years in current position and satisfaction with preparation programs beyond the association shown in Table 6, correlations were calculated between years in current position and the four subscale scores. The associations were not statistically or practically significant.

Table 6

Spearman Correlation Between Years in Current Position and Satisfaction with Program Preparation

\begin{tabular}{l|c|c|}
\hline \multicolumn{1}{c|}{ Category } & Correlation with years in current position & $\boldsymbol{P r}>|\boldsymbol{t}|$ \\
\hline Student Achievement & $r=-.037$ & .507 \\
School Management & $r=.006$ & .920 \\
Special Populations & $r=.096$ & .087 \\
Communication & $r=.049$ & .382 \\
\hline
\end{tabular}

$p<.05$

A histogram of the years in current position is shown in Figure 1. This graph shows that a majority of the principals have been in their current position for less than 10 years.

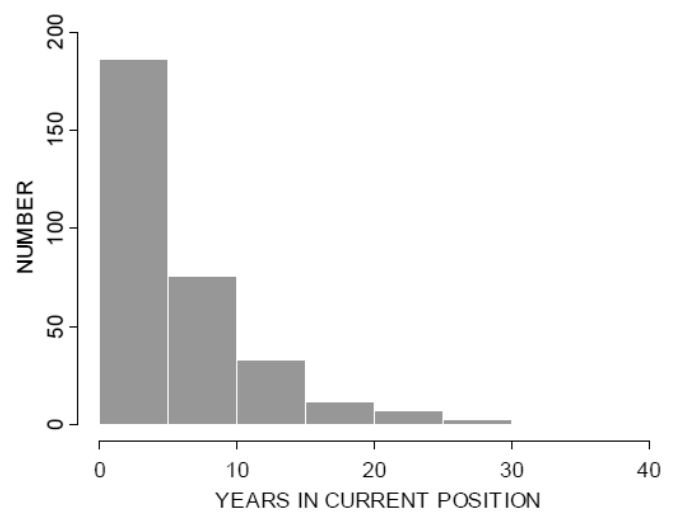

Figure 1. Histogram of years in current position. 


\section{DISCUSSION}

Findings pertaining to the first research question, gauging the levels of satisfaction pertaining to principal preparation programs, indicated that principals felt prepared to address their roles relative to student achievement, school management, and communication. The average percentage for some form of agreement that their preparation program has prepared them was $77 \%$. The researchers found these results noteworthy considering the inconsistency of these findings as compared with findings form other research previously cited.

In a study conducted by Farkas, Johnson, Duffett, Foleno, and Foley (2001) of principal preparation, 69\% of their respondents believed traditional principal preparation programs were not in touch with the true challenges of the principalship. Other studies have also included findings indicating deficiencies in principal preparation programs (Farkas, Johnson \& Duffet, 2003; SREB, 2005; Levine, 2005; United States Department of Education, 2005; Hess \& Kelley, 2007). The higher levels of satisfaction reported in this study pertaining to student achievement, school management, and communication may be caused by differences in the definition of satisfaction, differences in regions, or school grade levels as found throughout these multiple studies.

It should be noted, however, that although the level of satisfaction regarding student achievement, school management, and communication were high, the average percentage for some form of agreement that their program had prepared them pertaining to special populations was 56\%. These findings were more consistent with those presented in other studies (Goor, 1997; DiPaola \& Walther-Thomas, 2003) and also support the need to improve the preparation of principals relative to special population student achievement. Specifically, this finding could indicate a deficiency in preparation programs to fully develop supervisory and support strategies for differentiating instruction, regarded as the most effective way to improve student achievement among special populations (Gassenheimer, 2005; Gambrell, Morrow, \& Pressley, 2007).

Regarding the findings of the second research question, the difference in principal satisfaction levels between alternative and traditional preparation programs, there was no evidence of any difference in levels of satisfaction between those respondents who received alternative or traditional preparation. Of the 374 respondents, only 11 identified themselves as alternatively certified. Much to the surprise and disappointment of the researchers involved with this study was the difficulty experienced in identifying principals who were alternatively certified and the resulting low responses from this group. This could have resulted from the various manners in which states define alternative certification. Furthermore, information regarding those who were alternatively certified was difficult to locate on state department of education websites, and mailing information was equally as difficult to secure. It is postulated that the difficulties experienced by the researchers in identifying and locating administrators who had completed alternative preparation programs are not uncommon and may also be a significant factor in the relative void found in comparison studies regarding principal preparation programs.

There was also no evidence generated by the third research question, years in the position as a factor, to support a difference in the perceptions of preparation between respondents in their current position with less than 5 years' experience and with those who had 5 or more years' experience in their current position. Since there have been no significant changes in principal preparation programs (Hess \& Kelley, 2007), it is not surprising that years of experience was not a factor in determining principal satisfaction with preparation programs. As stated previously, what may be surprising is the high level of satisfaction reported by participants as compared to other comparable studies.

\section{CONCLUSION}

\section{Implications for Policy and Practice}

The authors of this work placed considerable value on the opinions expressed by practitioners therefore it was their intent to obtain data from current principals regarding their levels of satisfaction with their preparation programs. Since information was provided by those in the field greatly relying upon their preparation to meet the daily challenges of the principalship, their feedback should be useful to those involved with the design of principal preparation programs including university administrators. 
As documented by this study, greater emphasis should be place at the university level on the preparation of principals to address the needs of special populations. Areas dealing with the management of Individual Educational Programs (IEPs), behavior plans, and testing should be emphasized and integrated into coursework throughout the preparation program. Threading curriculum regarding legal issues, differentiated instruction, behavior management, and tests and measurements throughout preparation programs could strengthen areas of content connected to these topics.

Additionally, the inclusion of practitioners as guest speakers could provide valuable hands-on insights into addressing these topics through the connection of theory and practice.

\section{Recommendations For Future Research}

The authors of this work recommend that follow-up research be conducted to help expand the body of knowledge pertaining to administrator preparation programs. When conducting future studies on this topic, it is suggested the researchers:

1. Publish clear definitions of alternative and traditional preparation programs. It is suggested that a factor influencing the low responses of those identifying themselves as completing alternative certification was confusion regarding the differentiation between alternative and traditional preparation programs.

2. Expand the study to include additional regions of the country. The study was limited to states found within the southeastern region of the United States.

3. Replicate the study with other constructs aligned with factors influencing student achievement such as the 21 research-based responsibilities offered by the Mid-continent Research for Education (Mid-continent Research for Education and Learning, 2007).

\section{AUTHOR INFORMATION}

Dr. Ronald A. Styron, Jr. is Director of The University of Southern Mississippi Gulf Coast Instructional Leadership Center. Prior to his service as a University Professor, Dr. Styron served 18 years as a K-12 building-level administrator.

Dr. Steven Lemire is an Assistant Professor in the Department of Education Foundations and Research at the University of North Dakota. Dr. Lemire's areas of specialization include statistical analysis, biostatistics, quantitative research methods, multivariate analysis and design, and test construction.

\section{REFERENCES}

1. American Association of Colleges for Teacher Education. (1988). Education reform: Are we on the right track? Washington, DC: American Association of Colleges for Teacher Education.

2. Beck, L., \& Murphy, J. (1994). Ethics in educational leadership programs: An expanding role. Thousand Oaks, CA: Corwin Press.

3. DiPaola, M.F. \& Walther-Thomas, C. (2003). Principals and special education: The critical role of school leaders. Report prepared for the Center on Personal Studies in Special Education and the National Clearinghouse for Professions in Special Education.

4. Elmore, R. F. (2000). Building a new structure for school leadership. Washington, DC: The Albert Shanker Institute.

5. Farkas, S., Jean J., Duffett, A., Foleno, T., \& Foley, P. (2001). Trying to stay ahead of the game: Superintendents and principals talk about school leadership. Washington, D.C.: Public Agenda.

6. $\quad$ Farkas, S., Johnson, J., \& Duffet, A. (2003). Rolling up their sleeves: Superintendents and principals talk about what's needed to fix public schools. New York: Public Agenda.

7. Firestone, W. A., Schorr, R. Y., \& Monfils, L. F. (2004). The ambiguity of teaching to the test. Mahwah, NJ: Lawrence Erlbaum Associates.

8. Fuhrman, S., \& Elmore, R. (1990). Understanding local control in the wake of state education reform. Educational Evaluation and Policy Analysis, 12(1), 82-96. 
9. Gambrell, L. B., Morrow, L. M., Pressley, M., \& Guthrie, J. T. (2007). Best practices in literacy instruction. New York, NY: Guilford Press.

10. Gassenheimer, C. (2005). Report of the Southeast Regional Advisory Committee for Educational Needs Assessment. Retrieved January 4, 2008, from http://www.ed.gov.

11. Gates, S.M., Ringel, J.S., \& Santibanez, L. (2003). Who is leading our schools? An overview of school administrators and their careers. Santa Monica, CA: RAND.

12. Goor, M.B. (1997). Preparing principals for leadership in special education. Intervention in School and Clinic, 32(3), 133-141.

13. Hess, F. (2006). Looking beyond the schoolhouse door. Phi Delta Kappan, 87(7), 513-515.

14. Hess, F.M. \& Kelley, A.P. (2005). The politics of principal preparation reforms. Education Policy, 19(1), 155-180.

15. Hess, F. M., \& Kelley, A. P. (2007). Learning to lead: What gets taught in principal-preparation programs? Teachers College Record, 109(1), 244-274.

16. Levine, A. (2005). Educating school leaders. New York: Teachers College, The Education Schools Project.

17. Mid-continent Research for Education and Learning. (2007). Balanced leadership. Retrieved January 11, 2008 from http://www.mcrel.org.

18. Pounder, D. G., Galvin, P., \& Shepard, P. (2003). An analysis of the United States Educational administrator shortage. Australian Journal of Education, 47(2), 133-145.

19. Schmoker, M. (2003). First things first: Demystifying data analysis. Educational Leadership, 60(5), 22-24.

20. Southern Regional Education Board. (2004). Challenge to lead. Retrieved January 8, 2008 from http://sreb.org.

21. Southern Regional Education Board. (2007). Good leaders now: State progress in creating a learningcentered school leadership system. Retrieved December 5, 2007, from http://sreb.org.

22. Stiggins, R. J. (2002). Assessment crisis: The absence of assessment for learning. Phi Delta Kappan, 83(10), 758-765.

23. U.S. Department of Education National Center for Education Statistics. (2003). Retrieved January 24, 2008, from http://nces.ed.gov/surveys/sass/questions0304.asp.

24. U.S. Department of Education. (2003). Meeting the highly qualified teachers challenge. Jessup, MD: Editorial Publications Center.

25. U.S. Department of Education, Office of Innovation and Improvement. (2004). Innovative pathways to school leadership. Washington, DC: Office of Innovation and Improvement,

26. U.S. Department of Labor. (2007). Occupational outlook handbook, 2006-07. Retrieved September 12, 2007, from www.bls.gov.

27. Young, M., \& Brewer, C. (2008). Fear and the preparation of school leaders: The role of ambiguity, anxiety, and power in meaning making. Educational Policy, 22(1)106-129. 
NOTES 